\title{
Deoxyribonucleic Acid Homology Among Lactobacillus Species of the Subgenus Streptobacterium Orla-Jensen
}

\author{
F. DELLAGLIO, V. BOTTAZZI, AND MARISA VESCOVO
}

Istituti di Microbiologia Agraria e Tecnica e Microbiologia Lattiero-casearia, Facoltà di Agraria, Università Cattolica del Sacro Cuore, Piacenza, Italy

\begin{abstract}
The deoxyribonucleic acid (DNA) relationship among Lactobacillus species of the subgenus Streptobacterium Orla-Jensen was assessed by means of DNA/ DNA hybridization experiments. High genetic homologies were found among Lactobacillus casei subsp. casei, L. casei subsp. alactosus, L. casei subsp. pseudoplantarum, and $L$. casei subsp. tolerans; however, there was only a low level of homology between the DNA of $L$. casei subsp. rhamnosus and the DNA of other subspecies of L. casei. The DNAs of Lactobacterium zeae ATCC 15820 and $L$. casei subsp. casei ATCC 393 were nearly completely homologous. Although the latter strain has been proposed as the neotype for $L$. case $i$, it is not related to any of the other strains within the subspecies of $L$. casei. Lactobacillus plantarum and strains identified as belonging to $L$. plantarum subsp. rudensis and $L$. plantarum subsp. arabinosus formed a fairly homogeneous and easily recognized group. The DNA of Lactobacillus pentosus was unrelated to that of any known streptobacteria, and we therefore advocate the recognition of this organism as an independent species. There is a high degree of homology between Lactobacillus sake and Lactobacillus homohiochi; the name $L$. sake has priority, and $L$. homohiochi is very probably a synonym; for the same reason, Lactobacillus yamanashiensis has priority over its later subjective synonym, Lactobacillus mali. The general DNA/DNA homology relationships among Lactobacillus casei, $L$. plantarum, $L$. coryniformis, $L$. curvatus, $L$. xylosus, $L$. alimentarius, $L$. farciminis, and Sporolactobacillus inulinus justify their status as separate species.
\end{abstract}

In a previous deoxyribonucleic acid (DNA)DNA hybridization study on thermophilic lactobacilli (6), a close genetic relationship between Lactobacillus helveticus and Lactobacillus jugurti and also between Lactobacillus lactis and Lactobacillus bulgaricus was demonstrated. Their close phenotypic similarities were confirmed by genetic data.

Orla-Jensen (25) originally divided the subgenus Streptobacterium into only two species: Lactobacillus casei was described as a "typical cheese bacterium" and Lactobacillus plantarum was described as a "typical vegetable bacterium." Others have proposed Lactobacillus coryniformis (1), Lactobacillus curvatus (1), Lactobacillus sake (15), Lactobacillus homohiochi (17), Lactobacillus xylosus (16), Lactobacillus mali (5), Lactobacillus yamanashiensis (24), Lactobacillus farciminis (29), Lactobacillus alimentarius (29), and Sporolactobacillus inulinus (18) as members of the subgenus Streptobacterium.

Few DNA-DNA hybridization studies have been made on streptobacteria. Miller et al. (21) showed that there was a low homology $(50 \%)$ between $L$. casei subsp. casei and $L$. case $i$ subsp. rhamnosus, and that $L$. casei and $L$. plantarum are completely unrelated. Johnson (14) found high genetic similarity (77 to $100 \%$ ) between $L$. casei subsp. casei and $L$. casei subsp. alactosus, whereas $L$. casei subsp. casei and $L$. casei subsp. rhamnosus were poorly homologous (33 to 37\%). Mills and Lessel (22), in agreement with our presently reported results, found a close genetic similarity $(82 \%)$ between $L$. casei ATCC 393 , the neotype strain of $L$. casei subsp. casei, and Lactobacterium zeae ATCC 15820.

In this work, a large number of known and proposed Streptobacterium species was investigated by DNA-DNA hybridization duplex formation to determine if taxa considered species by phenotypic characters may also be considered as genotypic species.

\section{MATERIALS AND METHODS}

Bacterial strains. The Lactobacillus strains used in this work are listed in Table 1. Most of them were received from foreign collections. The authenticity of all strains was checked by comparing their main physiological characteristics with original descriptions, if available. 
TABLE 1. List of strains studied

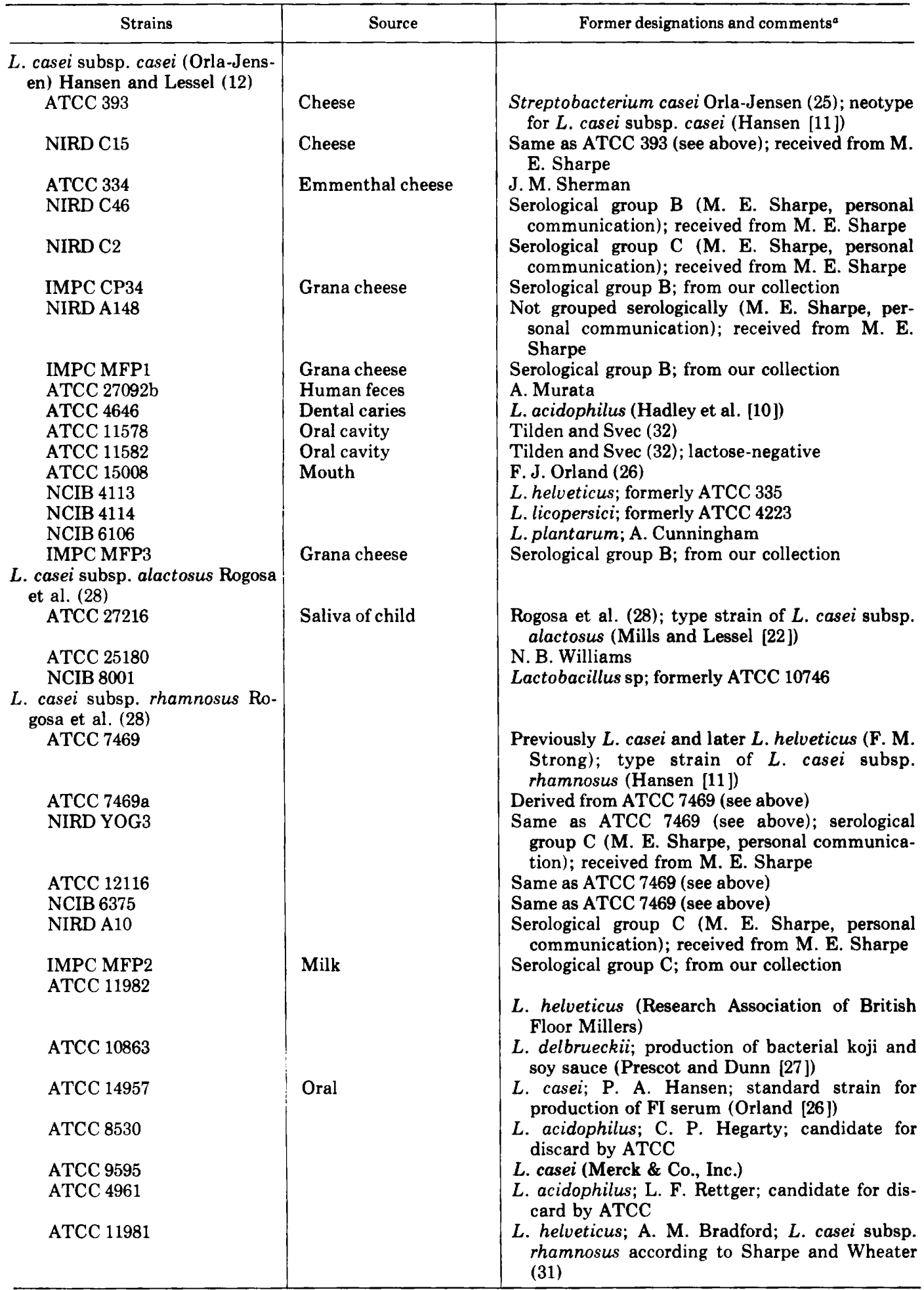


TABLE 1-Continued

\begin{tabular}{|c|c|c|}
\hline Strains & Source & Former designations and comments ${ }^{a}$ \\
\hline NIRD BR26 & & Received from M. E. Sharpe \\
\hline ATCC 13075 & Swiss cheese & R. G. Benedict; candidate for discard by ATCC \\
\hline ATCC 14435 & Grass silage & L. casei; Langston and Bouma (20); motile \\
\hline ATCC 15820 & Corn-steep liquor & $\begin{array}{l}\text { Type strain of Lactobacterium zeae Kuznetsov } \\
\text { (19); Syn. of L. casei (22) }\end{array}$ \\
\hline NCIB 9537 & Corn-steep liquor & Same as ATCC 15820 (see above) \\
\hline $\begin{array}{l}\text { L. casei subsp. } \\
\text { pseudoplantarum Abo-Elnaga } \\
\text { and Kandler (1) }\end{array}$ & & \\
\hline DSM 20008 & Milking machine & $\begin{array}{l}\text { Abo-Elnaga and Kandler (1); received from } \mathrm{N} \text {. } \\
\text { Weiss }\end{array}$ \\
\hline DSM 20207 & & $\begin{array}{l}\text { Abo-Elnaga and Kandler (1); received from } \mathrm{N} \text {. } \\
\text { Weiss }\end{array}$ \\
\hline $\begin{array}{l}\text { L. casei subsp. fusiformis } \\
\text { Eschenbecher (8) }\end{array}$ & & \\
\hline DSM 20006 & Beer & Eschenbecher (8); received from N. Weiss \\
\hline DSM 20013 & Beer & Eschenbecher (8); received from N. Weiss \\
\hline $\begin{array}{l}\text { L. casei subsp. tolerans Abo- } \\
\text { Elnaga and Kandler (1) }\end{array}$ & & \\
\hline DSM 20012 & Pasteurized milk & $\begin{array}{l}\text { Abo-Elnaga and Kandler (1); received from } \mathrm{N} \text {. } \\
\text { Weiss }\end{array}$ \\
\hline L. plantarum Bergey et al. (3) & & \\
\hline ATCC 14917 & Pickled cabbage & $\begin{array}{l}\text { Streptobacterium plantarum Orla-Jensen (25); } \\
\text { type strain of L. plantarum (Hansen [11]) }\end{array}$ \\
\hline ATCC 8014 & Corn silage & L. arabinosus (E. McCoy) \\
\hline NCIB 6376 & Corn silage & Same as ATCC 8014 (see above) \\
\hline NIRD P5 & & Received from M. E. Sharpe \\
\hline IMPC TL7 & Milk & From our collection \\
\hline NIRD P19 & & Received from M. E. Sharpe \\
\hline $\begin{array}{l}\text { ATCC } 14431 \\
\text { ATCC } 10012\end{array}$ & Grass silage & $\begin{array}{l}\text { Langston and Bouma (20); catalase positive } \\
\text { Streptobacterium plantarum (R. Kuhn); raf- } \\
\text { finose negative }\end{array}$ \\
\hline IMPC TL8 & Silage & From our collection \\
\hline NIRD SL7 & & Received from M. E. Sharpe \\
\hline NIRD AR5 & & Received from M. E. Sharpe \\
\hline NIRD P3 & & Received from M. E. Sharpe \\
\hline IMPC HP10 & Silage & From our collection \\
\hline ATCC 4008 & & L. acidophilus-aerogenes (C. S. Pederson) \\
\hline ATCC 11580 & Oral cavity & $\begin{array}{l}\text { Tilden et al. (32); candidate } \\
\text { for discard by ATCC }\end{array}$ \\
\hline ATCC 10241 & Sauerkraut & $\begin{array}{l}\text { M. Stephenson; type serum for L. plantarum; M. } \\
\text { E. Sharpe }(30)\end{array}$ \\
\hline ATCC 8008 & Butter & Orla-Jensen (25) \\
\hline ATCC 21028 & & $\begin{array}{l}\text { L. delbrueckii (Kyowa Ferm. Ind. Co. Ltd. KY } \\
\text { 3648); patent strain }\end{array}$ \\
\hline NIRD AB41 & & Received from M. E. Sharpe \\
\hline NCIB 1406 & Dental caries & $\begin{array}{l}\text { L. acidophilus-odontolyticus (J. J. McIntosh); } \\
\text { formerly ATCC } 11974\end{array}$ \\
\hline IMPC PC8 & Maize silage & From our collection \\
\hline NIRD P2 & & Received from M. E. Sharpe \\
\hline ATCC 10776 & & E. B. Fred; candidate for discard by ATCC \\
\hline ATCC 8041 & & L. pentosus (E. E. Snell) \\
\hline NCIB 8026 & & Same as ATCC 8041 (see above) \\
\hline ATCC 8292 & Fermenting olives & R. H. Vaughn; candidate for discard by ATCC \\
\hline NIRD P31 & & Received from M. E. Sharpe \\
\hline IMPC 2-18 & Cecal feces of turkeys & Harrison and Hansen (13); from our collection \\
\hline
\end{tabular}


TABLE 1-Continued

\begin{tabular}{|c|c|c|}
\hline Strains & Source & Former designations and comments ${ }^{a}$ \\
\hline $\begin{array}{l}\text { L. plantarum subsp. rudensis } \\
\text { (Davis and Mattick) Breed } \\
\text { and Pederson (J. Bacteriol. } \\
\text { 36:667) }\end{array}$ & & \\
\hline ATCC 13649 & Cheddar cheese & $\begin{array}{l}\text { Breed and Pederson (J. Bacteriol. 36:667); candi- } \\
\text { date for discard by ATCC }\end{array}$ \\
\hline \multicolumn{3}{|l|}{$\begin{array}{l}\text { L. coryniformis subsp. corynifor- } \\
\text { mis Abo-Elnaga and Kandler } \\
\text { (1) }\end{array}$} \\
\hline ATCC 25602 & Silage & $\begin{array}{l}\text { Abo-Elnaga and Kandler (1); suggested reference } \\
\text { strain for } L \text {. coryniformis subsp. coryniformis }\end{array}$ \\
\hline DSM 20001 & Silage & $\begin{array}{l}\text { Abo-Elnaga and Kandler (1); received from } \mathrm{N} \text {. } \\
\text { Weiss }\end{array}$ \\
\hline DSM 20007 & Silage & $\begin{array}{l}\text { Abo-Elnaga and Kandler (1); received from N. } \\
\text { Weiss }\end{array}$ \\
\hline \multicolumn{3}{|l|}{$\begin{array}{l}\text { L. coryniformis subsp. torquens } \\
\text { Abo-Elnaga and Kandler (1) }\end{array}$} \\
\hline ATCC 25600 & Cow dung & $\begin{array}{l}\text { Abo-Elnaga and Kandler (1); suggested reference } \\
\text { strain for } L \text {. coryniformis subsp. torquens }\end{array}$ \\
\hline DSM 20004 & Cow barn & $\begin{array}{l}\text { Abo-Elnaga and Kandler (1); received from } N \\
\text { Weiss }\end{array}$ \\
\hline DSM 20005 & Cow dung & $\begin{array}{l}\text { Abo-Elnaga and Kandler (1); received from } N \\
\text { Weiss }\end{array}$ \\
\hline \multicolumn{3}{|l|}{ L. sake Katagiri et al. (15) } \\
\hline ATCC 15521 & "Moto" starter of sake & Suggested type strain of $L$. sake by Kitahara \\
\hline ATCC 15578 & $\begin{array}{l}\text { Moto starter of sake } \\
\text { Moto starter of sake }\end{array}$ & $\begin{array}{l}\text { Same as ATCC } 15521 \text {; received from Kitahara } \\
\text { S. Fukui }\end{array}$ \\
\hline \multicolumn{3}{|l|}{$\begin{array}{l}\text { L. homohiochi Kitahara et al. } \\
\text { (17) }\end{array}$} \\
\hline $\begin{array}{l}\text { ATCC } 15434 \\
\text { L. } x \text { ylosus Kitahara (16) }\end{array}$ & Spoiled sake & T. Kaneko \\
\hline & "Anchu" mash & Suggested as type strain of $L . x y l o s u s$ by Kitahara \\
\hline $\begin{array}{l}\text { L. mali Carr and Davies (5) } \\
\text { ATCC } 27053\end{array}$ & Apple juice & $\begin{array}{l}\text { Carr and Davies (5); suggested reference strain for } \\
\text { L. mali; catalase-positive }\end{array}$ \\
\hline J 123 & Apple juice & $\begin{array}{l}\text { Carr and Davies (5); same as ATCC 27054; } \\
\text { catalase positive; received from Carr }\end{array}$ \\
\hline 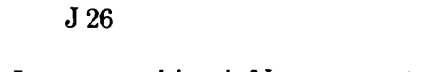 & Apple juice & $\begin{array}{l}\text { Carr and Davies (5); same as ATCC 27055; } \\
\text { catalase positive; received from Carr }\end{array}$ \\
\hline \multicolumn{3}{|l|}{$\begin{array}{l}\text { L. yamanashiensis Nonomura et } \\
\text { al. (24) }\end{array}$} \\
\hline I alimentarius Reuter (29) & Japanese wine & $\begin{array}{l}\text { Nonomura et al. (24); suggested reference strain } \\
\text { for } L . \text { yamanashiensis; motile; diaminopimelic } \\
\text { acid positive }\end{array}$ \\
\hline \multicolumn{3}{|l|}{ L. alimentarius Reuter (29) } \\
\hline $\begin{array}{l}\text { DSM } 20249 \\
\text { L. farciminis Reuter (29) }\end{array}$ & Meat products & Reuter (29); received from N. Weiss \\
\hline DSM 20180 & Meat products & Reuter (29); received from N. Weiss \\
\hline \multicolumn{3}{|l|}{$\begin{array}{l}\text { S. inulinus Kitahara and Suzuki } \\
\text { (18) }\end{array}$} \\
\hline $\mathrm{K} 15538$ & Chicken feed & $\begin{array}{l}\text { Kitahara and Suzuki (18); type strain of } S \text {. } \\
\text { inulinus; received from K. Kitahara }\end{array}$ \\
\hline $\begin{array}{l}\text { ATCC } 15538 \\
\text { NCIB } 9743\end{array}$ & Chicken feed & Same as K 15538 (see above) \\
\hline NCIB 9743 & Chicken feed & Same as K 15538 (see above) \\
\hline
\end{tabular}

a This information was obtained from culture collection catalogues or from the pertinent literature. Abbreviations and symbols: NIRD, National Institute for Research in Dairying, Reading, England; NCIB, National Collection of Industrial Bacteria, Aberdeen, Scotland; IMPC, Istituto di Microbiologia, Facoltà di Agraria, Piacenza, Italy; and J, J. G. Carr, University of Bristol, Bristol, England. For other abbreviations, see footnotes to Table 3 . 
Cultures of the strains were maintained on MRS agar (7) and propagated in MRS broth, except for $L$. homohiochi ATCC 15434, which was grown on MRS medium supplemented with mevalonic acid $(0.05$ g/liter).

The medium employed for labeling DNA was MRS broth containing added $\left[{ }^{14} \mathrm{C}\right]$ uracil and $\left[{ }^{14} \mathrm{C}\right]$ adenine (each $50 \gamma \mathrm{Ci} /$ liter). DNA preparations were purified and sheared. These conditions and those for DNA immobilization on membrane filters (Sartorius SM $11306)$ and DNA reassociation at $60 \mathrm{C}(25 \mathrm{C}$ below thermal denaturation $T$ ) have been described previously (6).

\section{RESULTS AND DISCUSSION}

The DNA homology values obtained are reported in Tables 2 and 3.

(i) L. casei subsp. casei (Orla-Jensen) Hansen and Lessel (12). The DNAs of 16 strains received as $L$. case $i$ subsp. case $i$ were hybridized with reference DNA from $L$. casei subsp. casei ATCC 393, L. casei subsp. casei ATCC 334, L. casei subsp. alactosus ATCC 27216, L. casei subsp. rhamnosus ATCC 7469, and $L$. plantarum ATCC 14917.

Only strain NIRD C15 shared a complete DNA relationship to $L$. casei subsp. casei ATCC 393. However, this is not surprising because NIRD $\mathrm{C} 15$ is the same as ATCC 393 (M. E. Sharpe, personal communication).

All other $L$. casei strains gave homology levels of 8 to $46 \%$ with strain ATCC 393 . Ten strains of L. casei gave homology values of 71 to $85 \%$ with reference DNA from $L$. casei subsp. casei ATCC 334 and nearly similar values of $75 \%$ to $99 \%$ with reference DNA from $L$. casei subsp. alactosus ATCC 27216.

Although ATCC strains 11582 and 15008 are listed in the ATCC catalogue (2) as $L$. case $i$ (Orla-Jensen) Hansen and Lessel, i.e., presumably $L$. casei subsp. casei, these strains ferment rhamnose and have the other phenotypic characteristics of $L$. casei subsp. rhamnosus. It is, therefore, not surprising that the DNA of these strains and that of the reference strain of $L$. casei subsp. rhamnosus ATCC 7469 are related (79 and 95\% for ATCC strains 11582 and 15008, respectively). Rhamnose fermentation occurred also in strains NIRD C2 and ATCC 11578, where there was high homology with reference DNA from $L$. casei subsp. casei ATCC 334 and L. casei subsp. alactosus ATCC 27216 . This is more difficult to explain because here phenotypy and genotypy do not appear to be correlated. NCIB 6106 is listed in the NCIB catalogue (23) as $L$. casei (Orla-Jensen) Holland; however, it was originally deposited as $L$. plantarum, and its present characteristics, including melibiose and raffinose fermentations, conform to those of $L$. plantarum and not to those of $L$. casei. The high level of homology (76\%) between NCIB 6106 and $L$. plantarum reference DNA is therefore to be expected.

(ii) L. zeae Kuznetsov [syn. L. casei (OrlaJensen) Hansen and Lessel (12)]. We received Kuznetsov's strain of $L$. zeae from the ATCC (ATCC 15820) as L. casei subsp. rhamnosus and from NCIB (NCIB 9537) as L. zeae. Our results confirm those obtained by Mills and Lessel (22): ATCC 15820 and NCIB 9537 were 80 and $84 \%$ homologous, respectively, to the reference strain L. case $i$ subsp. casei ATCC 393.

These strains were considerably less related to all other reference DNAs used.

L. casei subsp. casei ATCC 393 has been recently designated as the neotype strain of $L$. casei (12). However, our results indicated that only $L$. zeae ATCC 15820 (= NCIB 9537) is genetically homologous to this strain. Evidently the choice of the type strain for the species $L$. casei should be reconsidered.

(iii) L. casei subsp. alactosus Rogosa et al. (28). The three lactose-negative strains of $L$. casei subsp. alactosus studied (ATCC 27216, ATCC 25180, and NCIB 8001) competed to nearly the same high levels (from 78 to $91 \%$ ) with both $L$. casei subsp. alactosus ATCC 27216 (lactose negative) and $L$. casei subsp. casei ATCC 334 (lactose positive). Moreover, reciprocal hybridization of the reference DNAs from the latter two strains give similar high homology levels.

(iv) L. casei subsp. rhamnosus Rogosa et al. (28). Thirteen of the 17 strains received as $L$. casei subsp. rhamnosus formed a rather homologous group and displayed a close genetic relationship ( 80 to $106 \%$ ), with $L$. casei subsp. rhamnosus ATCC 7469 used as reference. The same strains showed lower levels of similarity to L. casei subsp. casei ATCC 393, L. casei subsp. casei ATCC $334, L$. casei subsp. alactosus ATCC 27216 , and $L$. plantarum ATCC 14917. Two strains (NIRD BR26 and ATCC 13075) were not related to the reference strain $L$. casei subsp. rhamnosus ATCC 7469, but they were homologous to $L$. case $i$ subsp. casei ATCC 334 and $L$. casei subsp. alactosus ATCC 27216.

We were not able to detect any fermentation of rhamnose by these two strains. (However, rhamnose fermentation by these strains was rechecked by $\mathrm{C}$. Mills and was found to be positive. Additional experiments are needed to resolve this matter.)

Only one strain (ATCC 14435), received as $L$. casei subsp. rhamnosus and isolated by Langston and Bouma (20), remained unassigned even though its DNA was tested in all our reference systems.

Our results strongly indicate that $L$. casei 
subsp. rhamnosus should not be considered as a subspecies but should be elevated to the rank of species.

(v) L. casei subsp. fusiformis Eschenbecher (8). The two strains (DSM 20006 and DSM 20013) received as $L$. casei subsp. fusifor$m i s$ were hybridized with almost all of our homologous systems, and one of them, DSM 20006, was found to be homologous with both $L$. casei subsp. casei ATCC 334 and L. case $i$ subsp. alactosus ATCC 27216, and the other, DSM 20013 , showed a high degree of homology $(80 \%)$ with $L$. casei subsp. rhamnosus ATCC 7469 reference DNA.

The fermentation patterns of these two strains are very different: DSM 20006 ferments maltose, melezitose, and mannitol and does not ferment rhamnose, lactose, or melibiose; DSM 20013 has the opposite reactions. Therefore, the recognition of this subspecies is seriously questioned.

(vi) L. casei subsp. pseudoplantarum AboElnaga and Kandler (1). The only two strains studied (DSM 20008 and DSM 20207) showed high genetic homologies ( 86 and $85 \%$, respectively) with $L$. case $i$ subsp. casei ATCC 334 and (98 and 93\%, respectively) with $L$. case $i$ subsp. alactosus ATCC 27216 as reference strains.

Their fermentation patterns were in accordance with the report of Abo-Elnaga and Kandler (1); in particular, these strains did not ferment rhamnose.

These two strains displayed some levels of DNA homology with $L$. plantarum used as reference. It is interesting to note that, although these strains undoubtedly belong to $L$. casei, they are somewhat more related genetically to L. plantarum ATCC 14917 than all other strains of $L$. casei (30 and $38 \%$, respectively [Table 2 ]).

(vii) L. casei subsp. tolerans Abo-Elnaga and Kandler (1). L. casei subsp. tolerans (DSM 20012), according to the description of AboElnaga and Kandler (1), ferments only lactose and galactose. Low DNA-DNA homology values were obtained with all reference DNAs except in the case of $L$. casei subsp. casei ATCC 334 and L. casei subsp. alactosus ATCC 27216, where the homology values were 71 and $82 \%$, respectively.

(viii) L. plantarum Bergey et al. (3). The DNAs of 20 of the 28 strains received as $L$. plantarum had similarity values ranging from 76 to $101 \%$ to the reference DNA of the type strain of $L$. plantarum ATCC 14917.

The other eight strains behaved quite differently. L. plantarum strains ATCC 8292 and NIRD P31 were only 57 and $65 \%$ homologous, respectively, to the reference ATCC 14917 , but were completely homologous to strain ATCC
8041 (L. pentosus) which was used as additional reference in the experiments with this species. $L$. plantarum NCIB 8026 is simply a deposit of strain ATCC 8041 in the NCIB. As expected, there was complete homology between the two DNA preparations.

ATCC 10776, NIRD P2, IMPC PC8, and ATCC 8008 were received as $L$. plantarum, but their DNAs were distinctly unrelated to $L$. plantarum and $L$. pentosus reference DNAs; furthermore, they were not related to ATCC 10776 used as additional reference DNA. Therefore, these strains were not assigned to any species.

In the interspecies hybridization tests, the DNAs of the $L$. plantarum strains showed little or no similarity with the $L$. casei DNAs used as reference, namely $L$. casei ATCC $393, L$. case $i$ ATCC $334, L$. casei subsp. alactosus ATCC 27216, and L. casei subsp. rhamnosus ATCC 7469.

Our results showed conclusively that the majority of the strains received as belonging to $L$. plantarum form a fairly homogeneous group whose DNA matched almost completely with the DNA of the type strain of this species, ATCC 14917.

However, three strains of $L$. plantarum which fermented xylose at variance with all other strains of this species behaved quite differently; their DNA annealed completely to the filterbound DNA obtained from ATCC 8041, formerly considered a representative of the species L. pentosus established by Fred et al. (9).

The lack of competition observed with the DNAs of these strains in all other homologous systems we used strongly suggests that this species might be reconsidered to be a valid specific taxon.

Apparently the same does not hold for $L$. arabinosus (9), because two strains, ATCC 8014 and NCIB 6376 , which were originally identified as belonging to $L$. arabinosus, were completely homologous to L. plantarum ATCC 14917 . This supports the widely accepted view, based on phenotypic characteristics, that these strains belong to $L$. plantarum.

(ix) L. coryniformis Abo-Elnaga and Kandler (1). Three strains (ATCC 25602, DSM 20001 , and DSM 20007) were received as $L$. coryniformis subsp. coryniformis and three (ATCC 25600, DSM 20004, and DSM 20005) as L. coryniformis subsp. torquens. Their DNAs competed to very high levels of homology ( 87 to $98 \%$ ) with reference DNA from $L$. coryniformis subsp. coryniformis ATCC 25602. There was little or no homology with the DNAs of any of the other reference systems. The fermentation pattems of these strains, including the inability 


\begin{tabular}{|c|c|c|c|c|c|c|c|c|}
\hline 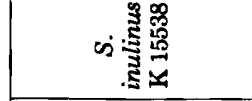 & 究 1 & 11 & 111111111111 & \& $\mid 1$ & 11 & 1 & 1 & 11 \\
\hline 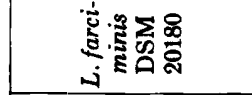 & จ 1 & 11 & 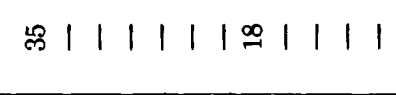 & कै। । & 11 & 1 & 1 & 11 \\
\hline 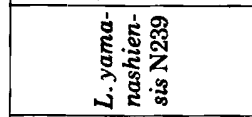 & $\stackrel{9}{2}$ & 11 & 胥 11111191111 & \pm 11 & 11 & 1 & 1 & 11 \\
\hline 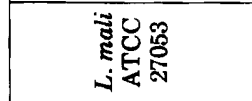 & $=1$ & 21 & $\infty 01111101111$ & 유 1 \& & $-\infty$ & 1 & - & 11 \\
\hline 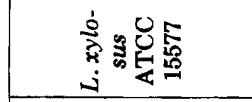 & 21 & 오 1 & $\infty|1| 1|1| 1|1| 1 \mid$ & 111 & 11 & 1 & 1 & 11 \\
\hline 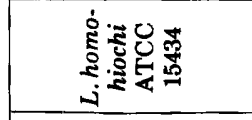 & $\stackrel{1}{1}$ & 11 & 1111111111111 & 111 & 01 & I & I & 11 \\
\hline 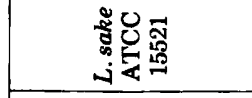 & 으오 & 11 & $\stackrel{\infty}{=}|1| 1 \mid 101111$ & $\stackrel{2}{\sim} 1$ & $\infty 1$ & I & 1 & 11 \\
\hline 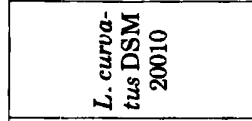 & 11 & 11 & $\infty|1| 1|1| 1|\infty| c|c| c \mid$ & 111 & \& 1 & $\overline{\mathrm{N}}$ & 1 & 11 \\
\hline 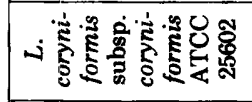 & $=1$ & $\cong 1$ & 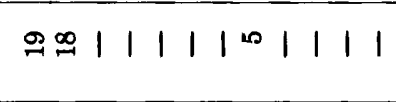 & 으윽 1 & $\infty 0$ & $\sigma$ & $\cong$ & 11 \\
\hline 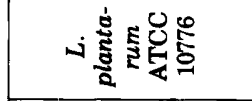 & i 1 & 11 & 111111111111 & 111 & 11 & 1 & 1 & 11 \\
\hline 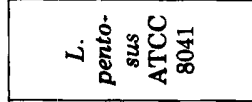 & $\vec{N} 1$ & 11 & $\approx 11111111111$ & 119 & Lo 1 & 1 & 1 & 11 \\
\hline 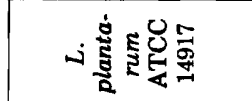 & no & $-\rightarrow$ & 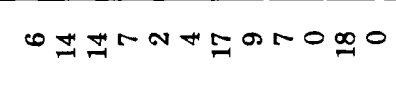 & 000 & ర్ల & 음 & 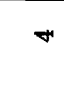 & æం \\
\hline 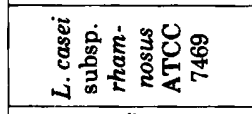 & $\mathscr{c} \mathscr{q}$ & 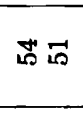 & 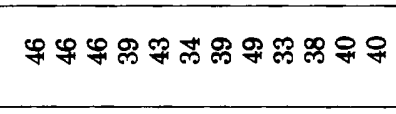 & ஒ & 5 & $\overline{\text { ล }}$ & $\infty$ & 央的 \\
\hline 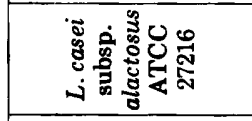 & $\infty$ & \& & 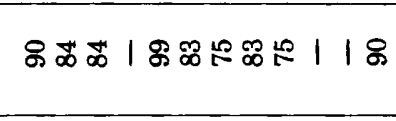 & 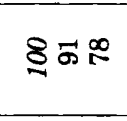 & œ & $\infty$ & 8 & $1 \infty$ \\
\hline 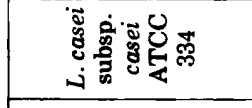 & $\mathscr{e}$ । & । ร & 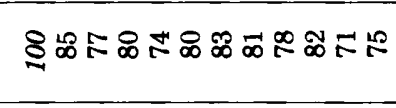 & $\mathscr{\infty} \infty \underset{2}{\infty}$ & $\mathscr{\infty}$ & F & R & $\infty \stackrel{\infty}{\infty}$ \\
\hline 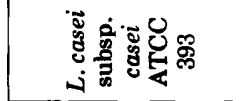 & $8 \%$ & ஓळ & 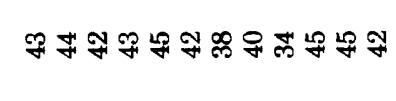 & 只与年 & $\curvearrowleft$ \& & 5 & 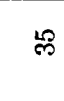 & $\infty$ \\
\hline 袁 & 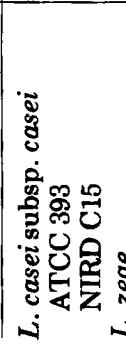 & 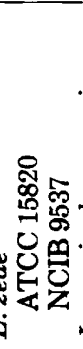 & 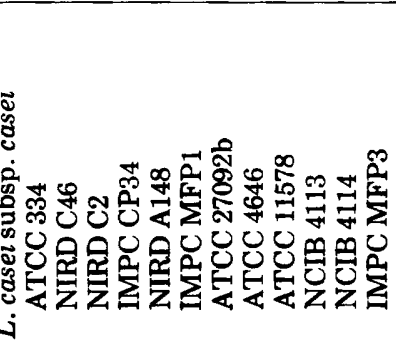 & 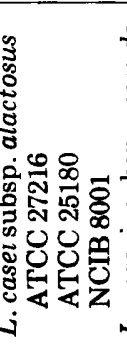 & 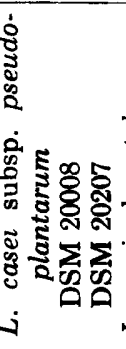 & 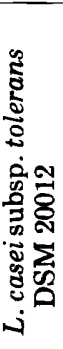 & 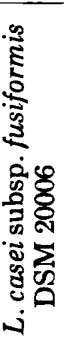 & 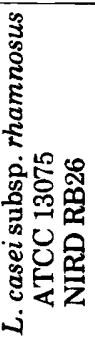 \\
\hline
\end{tabular}




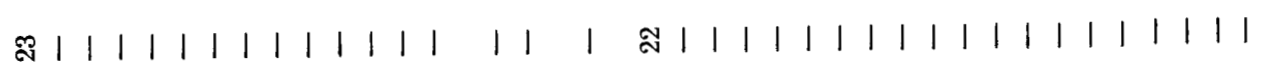

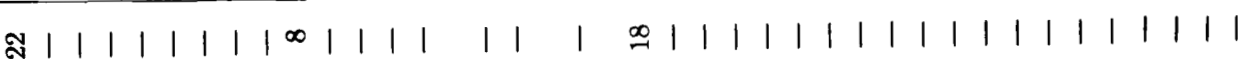

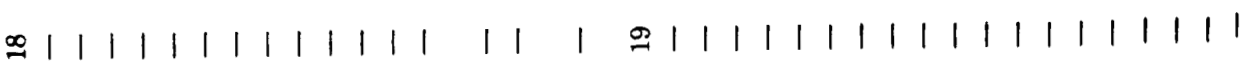

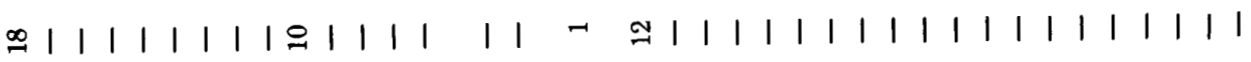

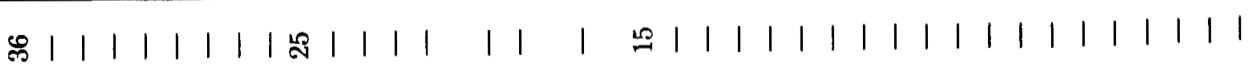

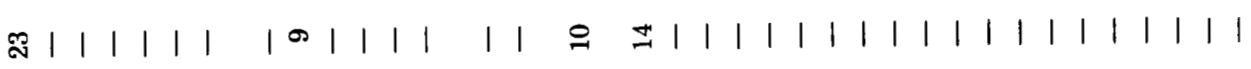

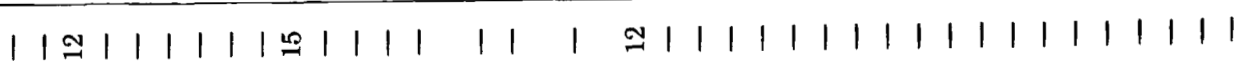

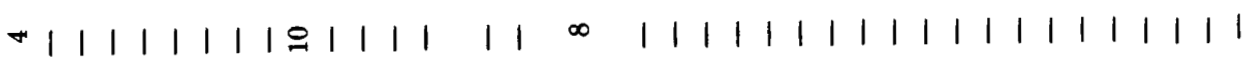
党 |

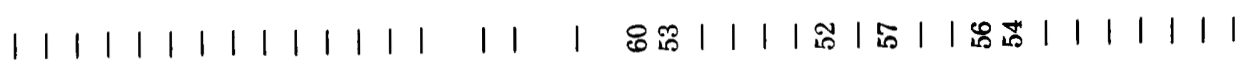

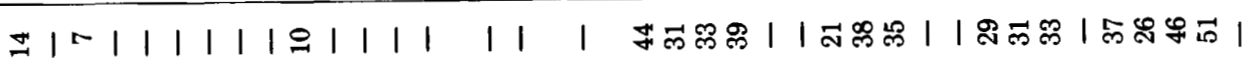

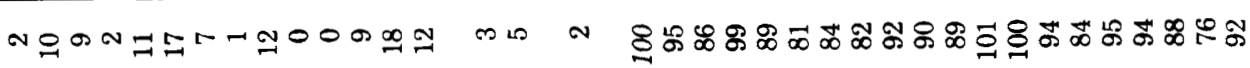

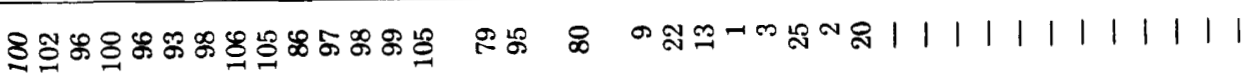
雨的员

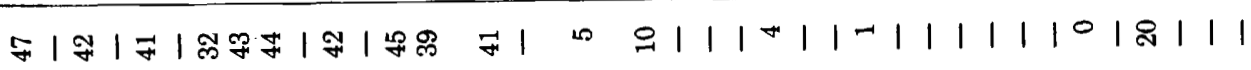

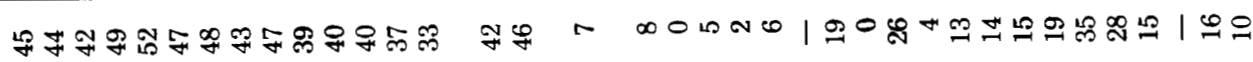

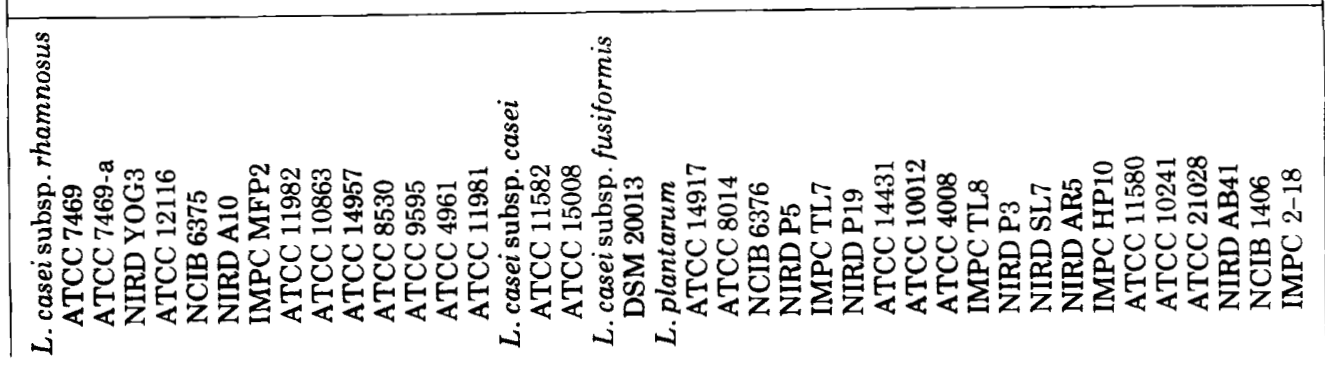




\begin{tabular}{|c|c|c|c|c|c|c|c|c|}
\hline 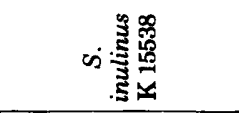 & I & 11 & 1 & 11111111 & -11 & $1 \mid 1$ & 11 & 1 \\
\hline 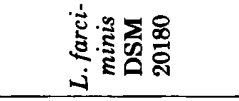 & 1 & 11 & $\dddot{2}$ & 11111111 & 足 $\mid 1$ & $1 \mid 1$ & 01 & 1 \\
\hline 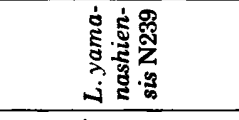 & I & 11 & $\vec{m}$ & 1111111 & 电 11 & 111 & 11 & $\stackrel{\infty}{\sim}$ \\
\hline 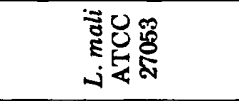 & 1 & 10 & $\dddot{2}$ & 1111111 & $0 \mid 1$ & 111 & $\infty 1$ & 0 \\
\hline 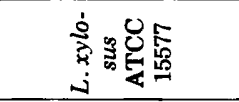 & 1 & 11 & 1 & 11111111 & $=11$ & 111 & ले। & 오 \\
\hline 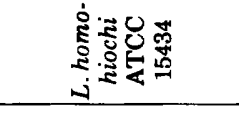 & 1 & 11 & 1 & 111111111 & 111 & 111 & 11 & 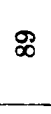 \\
\hline 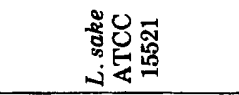 & 1 & 11 & 1 & 11111111 & 111 & 111 & 11 & 8 \\
\hline 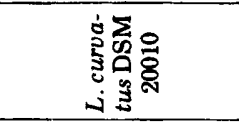 & 1 & 11 & r & 11111111 & \& । \& & ㅇ 11 & $8 \stackrel{0}{\circ}$ & ๘ \\
\hline 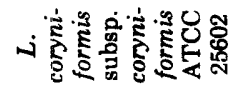 & 1 & 19 & 0 & 0111111 & 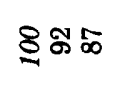 & ஜ $\infty カ ⿻$ & ర్ల న̃ & $\stackrel{9}{-}$ \\
\hline 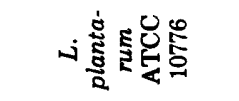 & I & 11 & F & 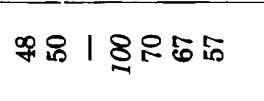 & 111 & 111 & 11 & 1 \\
\hline 小总解安志 & m & ำ 조 & 8 & 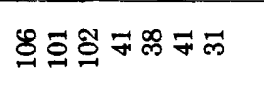 & $N \mid 1$ & 111 & $=\infty$ & $\stackrel{\infty}{=}$ \\
\hline 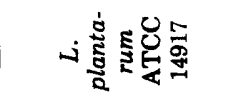 & ळ゙ & бஃ̊ & q & 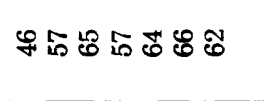 & $\mathscr{2} ㅇ$ & ล̊ & สี สิ & $\Rightarrow$ \\
\hline 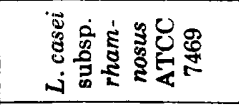 & I & $0 \vec{\infty}$ & 0 & 0110001 & $\pm \infty 1$ & $=\infty$ & 01 & 으 \\
\hline 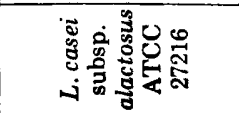 & 0 & $1 \infty$ & $\infty$ & 1 ooro- 1 & $* 11$ & 111 & -1 & $\mathfrak{I}$ \\
\hline 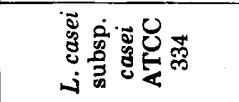 & 0 & $\therefore$ & $\infty$ & $1-1 \infty 010$ & 이 & $r-\infty$ & $\infty \pi$ & $\Xi$ \\
\hline 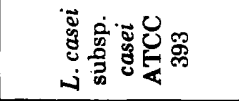 & 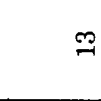 & $\infty \underset{\sim}{\sim}$ & $\mathscr{\varrho}$ & $\sigma \pi$ T & $\Rightarrow @ \infty$ & ODR & $\stackrel{2}{7}$ & $r$ \\
\hline 葭 & 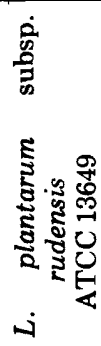 & 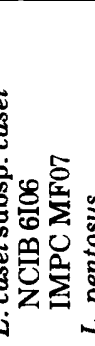 & 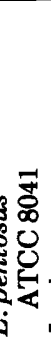 & 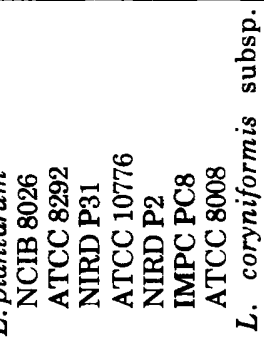 & 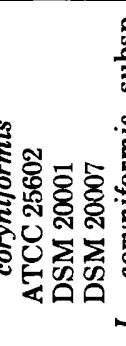 & 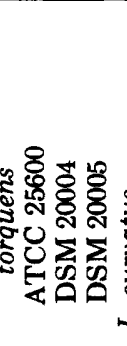 & 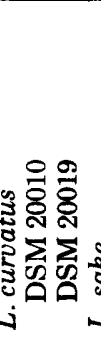 & 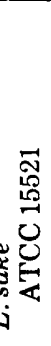 \\
\hline
\end{tabular}




\begin{tabular}{|c|c|c|c|c|c|c|c|c|}
\hline 11 & $\mathscr{a}$ & 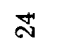 & $\vec{\infty} \mid 1$ & ల్ల & 11 & இூరの & $\mathscr{8}$ & J \\
\hline 11 & 1 & 1 & 011 & ล & $8 \infty$ & $\stackrel{\varrho}{0} 1$ & สิ & $\approx$ \\
\hline 11 & $\vec{N}$ & 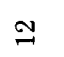 & 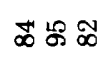 & 8 & $\stackrel{2}{-1}$ & ฆ | $\mid$ & ని & 9 \\
\hline or & $\mathscr{2}$ & 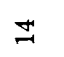 & இః & $\stackrel{\infty}{\infty}$ & $\infty 1$ & ㅇ 11 & $\Xi$ & 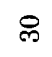 \\
\hline సี న & $\stackrel{\varrho}{\sim}$ & 8 & 111 & 1 & 11 & ส | | & $\mathscr{2}$ & ה \\
\hline $\mathscr{\infty}$ & 8 & 옹 & 111 & $\dddot{\pi}$ & 11 & $\dddot{m} \mid 1$ & $\cong$ & ล \\
\hline ธธ่ & $\stackrel{\infty}{\infty}$ & $\leftrightarrow$ & 111 & 1 & 11 & $\circ 11$ & $=$ & $F$ \\
\hline స 1 & $\tilde{\infty}$ & $\mathbb{N}$ & $\infty \mid 1$ & 0 & $\sim$ & $=11$ & $\Xi$ & $\infty$ \\
\hline 芯 ล & $\stackrel{\sim}{\sim}$ & $\vec{N}$ & 으음ㅇㅇ & 0 & ஜ & $=11$ & ล & $\overrightarrow{~ ल े ~}$ \\
\hline 11 & 1 & 1 & 111 & I & 11 & 111 & I & $r$ \\
\hline 1 & 음 & $\theta$ & \pm 11 & 1 & 11 & $0 \mid 1$ & $\vec{N}$ & 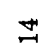 \\
\hline | & 우 & 응 & $=\infty$ & $\mathscr{2}$ & 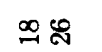 & $\approx 11$ & $\mathscr{\varphi}$ & $\stackrel{2}{2}$ \\
\hline 초으 & 19 & \& & $\infty+\infty$ & 요 & 10 เి & $\stackrel{\infty}{\sim} \mid$ | & $\cong$ & ลิ \\
\hline 11 & 1 & 1 & సి సే ని & $\mathscr{0}$ & $\therefore$ & 이 1 | & a & $\Rightarrow$ \\
\hline ন゙ & $\infty$ & $r$ & $r={ }^{+}$ & $\mathscr{0}$ & న : & $\approx 11$ & $\Xi$ & $\Rightarrow$ \\
\hline 1 ฉి & 19 & $\Xi$ & $10 N \forall$ & $\Xi$ & $\nexists \mathbb{A} \stackrel{2}{\sim}$ & $\stackrel{\infty}{=} \mid 1$ & $\mathbb{N}$ & 음 \\
\hline 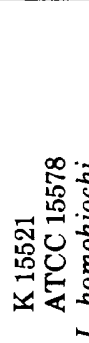 & & 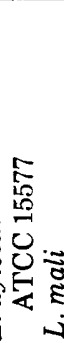 & 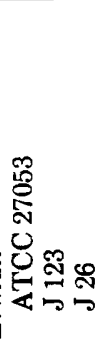 & & 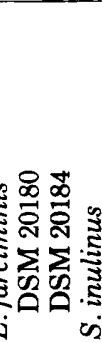 & 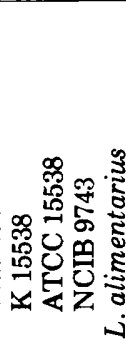 & 品 & 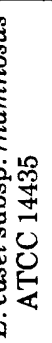 \\
\hline
\end{tabular}




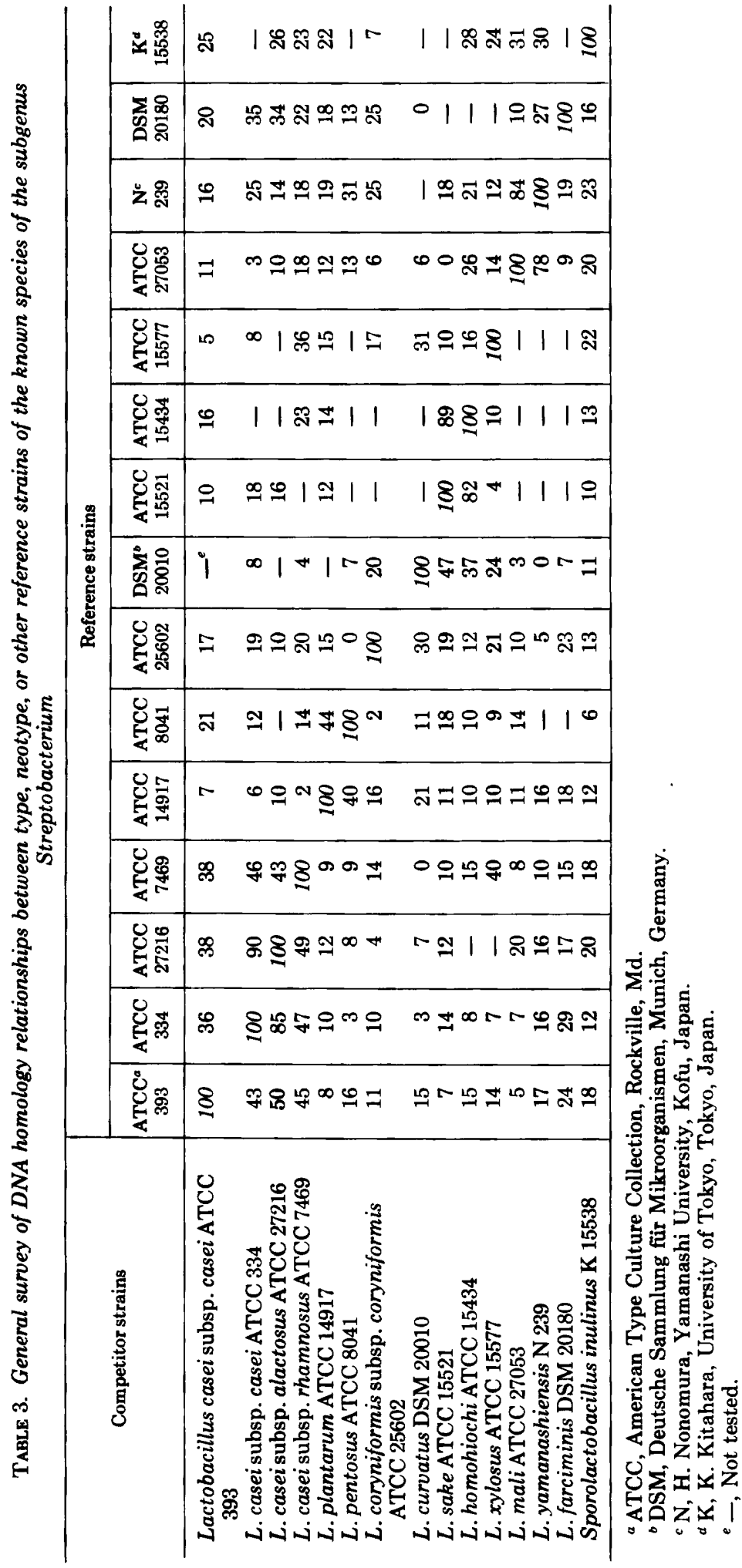


of L. coryniformis subsp. coryniformis to ferment lactose, agree with the original description given by Abo-Elnaga and Kandler (1).

(x) L. curvatus Abo-Elnaga and Kandler (1). The two strains (DSM 20010 and DSM 20019) received as $L$. curvatus were genetically identical and very distantly related, if at all, to other reference strains. Therefore, our results confirm the validity at the genetic level of the species established by Abo-Elnaga and Kandler (1), namely $L$. coryniformis and $L$. curvatus.

(xi) L. sake Katagiri et al. (15). ATCC 15521 , suggested as the type strain of $L$. sake, was used as DNA filter reference; $L$. sake ATCC 15578 was only $62 \%$ homologous to the reference.

Strain K 15521 , received directly from Kitahara, proved to be identical to strain ATCC 15521. The DNA homology was low with all other reference systems used.

The fermentation patterns of the two ATCC strains were different; ATCC 15521 fermented galactose, cellobiose, lactose, maltose, melibiose, sucrose, and trehalose while ATCC 15578 fermented galactose, cellobiose, lactose, maltose, sucrose, trehalose, melezitose, salicin, and mannitol.

(xii) L. homohiochi Kitahara et al. (17). Only one strain (ATCC 15434) of this species was studied in our competition experiments; it displayed a high level of similarity $(89 \%)$ only with $L$. sake ATCC 15521. Furthermore, reverse competition between the two strains gave the same high level of homology. The phenotypic characters of ATCC 15434 agree with those in the original description of L. homohiochi (17).

Our results concerning the species $L$. sake and $L$. homohiochi, although revealing homology levels that suggest the identity of these two species, should probably not be taken as definitive because they were based on a limited number of strains. It was clearly demonstrated that the strains of these two species studied are unrelated to any of the species of streptobacteria studied.

(xiii) L. xylosus Kitahara (16). The only strain of L. xylosus tested, ATCC 15577, displayed some level of homology only when tested with DNA from $L$. casei subsp. rhamnosus ATCC 7469 and showed almost zero homology with all other reference DNAs used. The phenotypic traits of ATCC 15577, the suggested type strain, agreed with the description of $L$. xylosus given by Kitahara (16). It is of interest to note that the DNA of ATCC 15577 is not related to the DNA of $L$. pentosus ATCC 8041, although both species are characterized by their behavior toward xylose.

(xiv) L. mali Carr and Davies (5). ATCC
27053 was used as reference for $L$. mali. Two additional strains of this species, $\mathrm{J} 123(=$ ATCC 27054) and J26 (= ATCC 27055), received directly from Carr, proved to be genetically identical to the selected reference.

The distinctive characteristics given by Carr and Davies (5) for this species, i.e., production of catalase and sugar fermentation patterns, were confirmed.

(xv) L. yamanashiensis Nonomura et al. (24). Nonomura's strain N239 displayed a high level of homology only with the reference $L$. mali ATCC 27053. Conversely, in DNA competition experiments, the three strains of $L$. mali showed similarity ranging from 82 to $95 \%$ when tested in the $L$. yamanashiensis reference system.

Some of the characters given by Nonomura et al. (24), e.g., motility, absence of catalase, and inability to ferment melibiose, raffinose, or arabinose, were checked in strain N239 and were found to correspond to those given in the original description of $L$. yamanashiensis. The close relationship between $L$. mali ATCC 27053 , L. mali ATCC 27055 , and N239 was indicated by the $\mathrm{G}+\mathrm{C}$ contents of their DNAs: ATCC $27053=32.5 \pm 0.15 \mathrm{~mol} \%$; ATCC $27055(\mathrm{~J} 26)=$ $32.2 \pm 0.12 \mathrm{~mol} \%$; and $\mathrm{N} 239=32.9 \pm 0.19$ $\mathrm{mol} \%$.

Although our results suggested a very close relationship between $L$. mali and $L$. yamanashiensis, one must bear in mind that only very few strains of both species were studied. The difference in the phenotypic characters of these organisms (J. G. Carr, personal communication) suggests that a larger number of strains must be studied to obtain conclusive results.

(xvi) L. farciminis Reuter (29). $L$. farciminis DSM 20180 was used as reference. Strain DSM 20184 displayed 88\% homology to the reference, suggesting a high degree of genetic relationship. Insignificant reassociation was found with all other competitors used.

The relevant physiological characters of this strain as given by Reuter (29) were confirmed by our tests.

(xvii) L. alimentarius Reuter (29). $L$. alimentarius DSM 20249 was genetically unrelated to all of our competition systems.

The phenotypic traits of this strain checked by us agree with those given in Reuter's (29) original description of this species.

Reuter's two species appear to be valid, but additional data are required to confirm this.

(xviii) S. inulinus Kitahara and Suzuki (18). S. inulinus K 15538 , received directly from Kitahara, was used as reference strain. As expected, S. inulinus ATCC 15538 and NCIB 
9743, subcultures from the same strain deposited by Kitahara in both collections, were highly homologous (91 and $84 \%$, respectively).

The same fermentation patterns, absence of catalase, formation of spores, and motility, were found in ATCC 15538 and NCIB 9743 in accordance with the description of $S$. inulinus by Kitahara and Suzuki (18).

Although we did not test all of our DNA competitors against the $S$. inulinus reference strain ( $\mathrm{K}$ 15538), our data are sufficient to permit the conclusion that this species is genetically distinct from the other species considered in this investigation.

\section{ACKNOWLEDGMENTS}

This investigation was supported by a grant from the Consiglio Nazionale delle Ricerche, Rome, Italy. We are indebted to V. Scardovi, University of Bologna, Italy for helpful comments and critical remarks. We thank E. Bosi, Istituti di Microbiologia, Facoltà di Agraria, Piacenza, Italy, for technical assistance.

\section{REPRINT REQUESTS}

Requests for reprints of this article may be addressed to: Dr. Franco Dellaglio, Instituti di Microbiologia Agraria e Tecnica e Microbiologia Lattiero-casearia, Università Cattolica del Sacro Cuore, Piacenza, Italia.

\section{LITERATURE CITED}

1. Abo-Elnaga, I. G., and O. Kandler. 1965. Zur Taxonomie der Gattung Lactobacillus Beijerinck. $I^{\circ}$ Das Subgenus Streptobacterium Orla-Jensen. Zentralbl. Bakteriol. II 119:1-36.

2. American Type Culture Collection. 1972. Catalogue of strains, 10th ed. American Type Culture Collection, Rockville, Md.

3. Bergey, D. H., F. C. Harrison, R. S. Breed, B. W. Hammer, and F. M. Huntoon. 1923. Bergey's manual of determinative bacteriology, 1st ed. The Williams \& Wilkins Co., Baltimore.

4. Brenner, D. J. 1973. Deoxyribonucleic acid reassociation in the taxonomy of enteric bacteria. Int. J. Syst. Bacteriol. 23:298-307.

5. Carr, J. G., and P. A. Davies, 1970. Homofermentative lactobacilli of ciders including Lactobacillus mali nov. spec. J. Appl. Bacteriol. 33:768-774.

6. Dellaglio, F., V. Bottazzi, and L. D. Trovatelli. 1973 Deoxyribonucleic acid homology and base composition in some thermophilic lactobacilli. J. Gen. Microbiol. 74:289-297.

7. de Man, J. G., M. Rogosa, and M. E. Sharpe. 1960. A medium used for the cultivation of lactobacilli. J. Appl. Bacteriol. 23:130-135.

8. Eschenbecher, F. 1968. Beer-spoilage lactobacilli. Brauwissenschaft 21:424-437.

9. Fred, E. B., W. H. Peterson, and J. A. Anderson. 1921. The characteristics of certain pentose destroying bacteria, especially as concerns their action on arabinose. $\mathrm{J}$. Biol. Chem. 48:385-412.

10. Hadley, F. P., R. W. Bunting, and E. A. Delves. 1930. Recognition of Bacillus acidophilus associated with dental caries: a preliminary report. J. Am. Dent. Ass. 17:2041.

11. Hansen, P. A. 1968. Type strains of Lactobacillus species.
A report by the Taxonomic Subcommittee on Lactobacilli and Closely Related Organisms. American Type Culture Collection, Rockville, Md.

12. Hansen, P. A., and E. F. Lessel. 1971. Lactobacillus casei (Orla-Jensen) comb. nov. Int. J. Syst. Bacteriol. 21:69-71.

13. Harrison, A. P., Jr., and P. A. Hansen. 1950. A motile Lactobacillus from the cecal feces of turkeys. J. Bacteriol. 59:444-446.

14. Johnson, J. L. 1973. Use of nucleic acid homologies in the taxonomy of anaerobic bacteria. Int. J. Syst. Bacteriol. 23:308-315.

15. Katagiri, H., K. Kitahara, and K. Fukami. 1934. The characteristics of the lactic acid bacteria isolated from moto, yeast mashes for sake manufacture. IV. Classification of the lactic acid bacteria. Bull. Agric. Chem. Soc. Jpn. 10:156-157.

16. Kitahara, K. 1940. Studies on the lactic acid bacteria isolated from mashes of various kinds of cereals. Bull. Agric. Chem. Soc. Jpn. 16:123.

17. Kitahara, K., T. Kaneko, and O. Goto. 1957. Taxonomic studies on the hiochi-bacteria specific saprophytes of sake. II. Identification and classification of hiochi-bacteria. J. Gen. Appl. Microbiol. 3:111-120.

18. Kitahara, K., and J. Suzuki. 1963. Sporolactobacillus nov. subgen. J. Gen. Appl. Microbiol. 9:59-71.

19. Kuznetsov, V. D. 1959. A new species of lactic acid bacteria. Mikrobiologiya 28:248-251.

20. Langston, C. W., and C. Bouma. 1960. A study of the microorganisms from grass silage. II. The lactobacilli. Appl. Microbiol. 8:223-234.

21. Miller, A., III, W. E. Sandine, and P. R. Elliker. 1971. Deoxyribonucleic acid homology in the genus Lactobacillus. Can. J. Microbiol. 17:625-630.

22. Mills, C. K., and E. F. Lessel. 1973. Lactobacterium zeae Kuznetsov, a later subjective synonym of Lactobacillus casei (Orla-Jensen) Hansen and Lessel. Int. J. Syst. Bacteriol. 23:430-432.

23. National Collection of Industrial Bacteria. 1964. Catalogue of strains, 2nd ed. National Collection of Industrial Bacteria, Aberdeen, Scotland.

24. Nonomura, H., T. Yamazaki, and Y. Ohara. 1965. Die Appelsaure-Milchsare-Bakterien, welche aus japanischen Weinen isoliert wurden. Mitt. Klosterneuburg 15A:241-254.

25. Orla-Jensen, S. 1919. The lactic acid bacteria. Andr. Fed. Host \& Son, Copenhagen.

26. Orland, F. I. 1950. A correlation of antigenic characteristics among certain bacteria of Lactobacillus group. J. Infect. Dis. 86:63-80.

27. Prescot, S. C., and C. G. Dunn. 1959. Industrial microbiology, p. 676. McGraw-Hill Book Co. Inc. New York.

28. Rogosa, M., R. F. Wiseman, J. A. Mitchell, M. N. Disraely, and A. J. Beaman. 1953. Species differentiation of oral lactobacilli from man including description of Lactobacillus salivarius nov. sp. and Lactobacillus cellobiosus nov. sp. J. Bacteriol. 65:681-699.

29. Reuter, G. 1970. Laktobazillen und eng verwandte Mikroorganismen in Fleisch und Fleischerzeugnissen 2. Mitt.: Die Charakterisierung der isolierten Laktobazillenstamme. Fleischwirtschaft 50:954-962.

30. Sharpe, M. E. 1955. A serological classification of lactobacilli. J. Gen. Microbiol. 12:107-122.

31. Sharpe, M. E., and D. M. Wheater. 1957. Lactobacillus helveticus. J. Gen. Microbiol. 16:676-679.

32. Tilden, E. B., and M. Svec. 1952. Further studies on a differential culture technique for estimation of acidogenic bacteria in saliva. II. Species of lactobacilli isolated from saliva and their distribution in a group of children. J. Dent. Res. 31:831-838. 